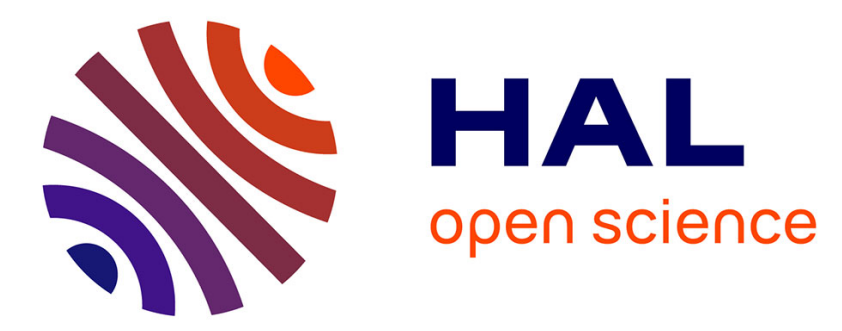

\title{
Radium as internal tracer of Mediterranean Outflow Water
}

\author{
Sabine Schmidt, Jean-Louis Reyss
}

\section{To cite this version:}

Sabine Schmidt, Jean-Louis Reyss. Radium as internal tracer of Mediterranean Outflow Water. Journal of Geophysical Research. Oceans, 1996, 101 (C2), pp.3589-3596. 10.1029/95JC03308 . hal03545638

\section{HAL Id: hal-03545638 \\ https://hal.science/hal-03545638}

Submitted on 27 Jan 2022

HAL is a multi-disciplinary open access archive for the deposit and dissemination of scientific research documents, whether they are published or not. The documents may come from teaching and research institutions in France or abroad, or from public or private research centers.
L'archive ouverte pluridisciplinaire HAL, est destinée au dépôt et à la diffusion de documents scientifiques de niveau recherche, publiés ou non, émanant des établissements d'enseignement et de recherche français ou étrangers, des laboratoires publics ou privés. 


\title{
Radium as internal tracer of Mediterranean Outflow Water
}

\author{
Sabine Schmidt and Jean-Louis Reyss \\ Centre des Faibles Radioactivités, Laboratoire Mixte Centre National de la Recherche Scientifique - Commissariat à \\ l'Energie Atomique, Gif sur Yvette, France
}

\begin{abstract}
Radium-226 and 228Ra data are presented for the Western Mediterranean Sea and the NE Atlantic. In the NW Mediterranean Sea, the near-shore surface waters of the Ligurian Current contain much higher ${ }^{228} \mathrm{Ra}$ concentrations than surface waters collected in the open Ligurian seawater. The gradient of ${ }^{228} \mathrm{Ra}$ along a Villefranche - Calvi transect has been used to calculate values of the horizontal eddy diffusion coefficient perpendicular to the flow direction of the Ligurian Current of about $10^{6} \mathrm{~cm}^{2} \mathrm{~s}^{-1}$. The observed decay of $228 \mathrm{Ra}$, as the Mediterranean Deep Water flows toward the Gibraltar Straits, is in good agreement with the assumption of a rapid turnover of the Mediterranean basin. Concentration profiles of ${ }^{226} \mathrm{Ra}$ and $228 \mathrm{Ra}$ were measured in the Mediterranean Outflow Water (MOW) off the Gibraltar Straits in the NE Atlantic basin at two stations, $36^{\circ} 30^{\prime} \mathrm{N}-15^{\circ} 35 \mathrm{~W}$ and $36^{\circ} 27^{\prime} \mathrm{N}-10^{\circ} 35^{\prime} \mathrm{W}$. These sites showed the hydrographic characteristics of Meddies (MOW which propagates as eddies in the NE Atlantic) at intermediate depth. At the center of the Meddies, around $1000 \mathrm{~m}$ depth, the activity of the short half-life $228 \mathrm{Ra}$ increases up to $0.9 \times 10^{-2}$ disintegrations per minute per liter, higher than usually found in North Atlantic Deep Water. This "young" 228Ra results from the contact, a few months earlier, of the MOW with the Spanish continental shelf in the vicinity of the Gibraltar Straits. The decay of ${ }^{228} \mathrm{Ra}$, used as an internal tracer of water mass motion, leads to a transit time of the Meddy Yseult of less than 1 year since its formation.
\end{abstract}

\section{Introduction}

Mediterranean Outflow Water (MOW) produces a warm and saline layer at around $1000 \mathrm{~m}$ in the NE Atlantic Ocean. This Mediterranean Water displays chemical and biological properties which are different from those of the surrounding Atlantic Water [Savenkoff et al., 1993]. MOW can propagate as eddies, called Meddies. Meddies are mesoscale features, typically $40-100 \mathrm{~km}$ in diameter with mean life around 3 years [Armi et al., 1988; Rossby, 1988]. Their formation process begins when MOW crosses the Gibraltar Strait. The presence of Meddies has implications for lateral dispersion of heat, salt, and pollutants [Marshall, 1988].

To explain the biological and chemical composition of Meddies, it is necessary to define the characteristics of the MOW which constitutes most of the water mass of Meddies and to evaluate the translation velocity. The time elapsed since the formation of a Meddy is useful for interpreting the composition of the saline water and for evaluating its influence on the surrounding environment.

Much effort has been devoted to the study of Meddies off the Canaries archipelago. Most of this has involved hydrodynamic study of the motion of one Meddy, tracked with drifting buoys [Armi et al., 1989]. The quantitative evaluation of large-scale mixing across ocean basins is also possible from the determination of naturally occurring radioisotopes, ${ }^{228} \mathrm{Ra}\left(t_{1 / 2}=5.75\right.$ years $)$ and ${ }^{226} \mathrm{Ra}\left(t_{1 / 2}=1600\right.$ years) [Kaufman et al., 1973; Sarmiento et al., 1982; Moore and Santschi, 1986]. Both $\mathrm{Ra}$ isotopes are supplied to the ocean by deep-sea and continental shelf sediments. A water mass in contact with sediment is enriched with $\mathrm{Ra}$ diffusing

Copyright 1996 by the American Geophysical Union.

Paper number 95JC03308.

0148-0227/96/95JC-03308\$05.00 out of sediments. The ${ }^{228} \mathrm{Ra} / 226 \mathrm{Ra}$ activity ratio will only change by dilution and radioactive decay after the water is isolated from sedimentary input. The ${ }^{228} \mathrm{Ra} /{ }^{226} \mathrm{Ra}$ ratio will decrease with increasing distance from sediments and with depth within the thermocline [Yamada and Nozaki, 1986; Reid et al., 1979; Moore and Todd, 1993]. The 228 Ra half-life is thus suitable for studying oceanic processes occurring on a 1- to 30-year timescale.

The objective of the work described herein has been to determine the temporal evolution of Meddies. The study concerns their origin, and in particular the Deep Mediterranean Water, and the comparison of two Meddies at different states. We used $226 \mathrm{Ra}$ and $228 \mathrm{Ra}$ tracers and associated physical measurements. Significant efforts have been necessary to improve sampling and analytical methods for radium isotopes.

\section{Methods}

Radium determinations were made on water samples collected from different sites in the NW Mediterranean Sea and NE Atlantic Ocean to follow Deep Mediterranean Water motion. The geographical location of stations is shown in Figure 1. To survey Meddies, which are anomalous in their temperature and salinity characteristics compared with the surrounding water masses (typically $>11.9^{\circ} \mathrm{C}$ and 36.2 practical salinity unit (psu)). These profiles led us to select two sites for which temperature and salinity indicated the presence of Meddies at intermediate depths: $36^{\circ} 27^{\prime} \mathrm{N}$ $10^{\circ} 35^{\prime} \mathrm{W}$ (Medatlante 1 - January 1989 - Nicole) and $36^{\circ} 30^{\prime} \mathrm{N}-15^{\circ} 35^{\prime} \mathrm{W}$ (Medatlante 2 - August 1989 -Yseult).

In seawater the very low ${ }^{228} \mathrm{Ra}$ content of about $5 \times 10^{-3}$ disintegrations per minute per liter (dpm L $\left.{ }^{-1}\right)$ implies either the extraction of $\mathrm{Ra}$ from large volume of seawater or more sensitive measurement methods [Orr, 1988]. First, we used large volumes of seawater sampled with a submersible, 
battery-powered pumping system developed at Centre des Faibles Radioactivités (CFR). In this way, 300 to $800 \mathrm{~L}$ of water were filtered in situ. The water was forced through a membrane filter (0.4- $\mu \mathrm{m}$ pore size), then through a $\mathrm{MnO}_{2}$ coated cartridge previously prepared at the laboratory with a procedure based on that of Reid et al. [1979], and finally through a flowmeter to record the volume of filtered water. The cartridge efficiency for $\mathrm{Ra}$ was obtained from an independent 30-L sample on which ${ }^{226} \mathrm{Ra}$ specific activity was measured.

For radiochemical analyses, the cartridge was soaked with hot concentrated $\mathrm{HCl}$ in the presence of a small amount of reducing agent (hydroxylamine hydrochloride). When the digestion was performed, the cartridge was removed and rinsed with deionized water. $\mathrm{Ra}$ was isolated by coprecipitation with a $\mathrm{Ba}$ carrier. Our $\mathrm{BaCO}_{3}$ carrier has a radium activity less than $0.005 \mathrm{dpm} / \mathrm{g}$. The precipitate was recovered, rinsed with $8 \mathrm{~N} \mathrm{HCl}$ and dried prior to analysis by $\gamma$ spectrometry. The two standards used for the calibration of the $\gamma$ detector are (1) a mock-up of sediment and $U$ and Th U.S. standards from National Bureau of Standards at $1000 \mathrm{ppm}$ and (2) a matrix formed by precipitation of sulphates in the presence of a $\mathrm{Ba}$ solution enriched with ${ }^{226} \mathrm{Ra}$ standard (Harwell) [Reyss et al., 1995]. The efficiency of Ra extraction by $\mathrm{BaSO}_{4}$ precipitation was obtained in two ways: by calculating the weight ratio of recovered $\mathrm{BaSO}_{4}$ to introduced $\mathrm{BaCO}_{3}$ (corrected by a mass factor of 1.18) and by measuring ${ }^{225} \mathrm{Ra}$, counted along with ${ }^{228} \mathrm{Ra}$, this spike being added prior to extraction. Extraction efficiencies are in the range $75-100 \%$, with good agreement between the two methods. On the 30-L sample, we isolated ${ }^{226} \mathrm{Ra}$ by coprecipitation with $\mathrm{Ba}(\mathrm{SO})_{4}$. The subsequent treatment was the same as described above.

A $220-\mathrm{cm}^{3}$ low-background, well-type gamma ray detector in the Laboratoire Souterrain de Modane (LSM - Centre National de la Recherche Scientifique (CNRS)/Commissariat à l'Energie Atomique (CEA)), allows us to measure ${ }^{228} \mathrm{Ra}$ from only $30 \mathrm{~L}$. of seawater with a precision of $\pm 15 \%$ for activity levels lower than $5 \times 10^{-3} \mathrm{dpm} \mathrm{L}^{-1}$. Thus during Medatlante 2, we used only $30-\mathrm{L}$ samples on which we isolated and measured ${ }^{226} \mathrm{Ra}$ and ${ }^{228} \mathrm{Ra}$ as described above. This new experimental strategy allows a larger number of analyses with reduced shiptime and laboratory effort.

\section{Results and Discussion \\ Mediterranean Basin}

Ligurian Sea. Radionuclide concentrations are listed Table 1. The Western Deep Mediterranean Water is one of the

Table 1. Results

\begin{tabular}{|c|c|c|c|c|c|c|c|}
\hline \multicolumn{2}{|l|}{ Stations } & \multirow[t]{2}{*}{$\begin{array}{l}\text { Depth, } \\
\text { m }\end{array}$} & \multirow[t]{2}{*}{$\begin{array}{l}226 \mathrm{Ra} \\
10^{-2} \mathrm{dpm} \mathrm{L-1}\end{array}$} & \multirow{2}{*}{$\begin{array}{c}\begin{array}{c}228 \mathrm{Ra} \\
10^{-2} \mathrm{dpm} \mathrm{L}\end{array} \\
\text { Dyfamed }\end{array}$} & \multirow[t]{2}{*}{${ }^{228} \mathrm{Ra} /{ }^{226} \mathrm{Ra}$} & \multirow[t]{2}{*}{$\begin{array}{l}\text { Salinity, } \\
\text { psu }\end{array}$} & \multirow[t]{2}{*}{$\begin{array}{c}\text { Temperature, } \\
{ }^{\circ} \mathrm{C}\end{array}$} \\
\hline & & & & & & & \\
\hline Transect & Bay & 10 & $12.25 \pm 3.75$ & $4.00 \pm 0.90$ & $0.324 \pm 0.122$ & & \\
\hline 4 km & & 10 & $9.90 \pm 0.40$ & $2.68 \pm 0.35$ & $0.270 \pm 0.035$ & & \\
\hline $15 \mathrm{~km}$ & & 10 & $9.81 \pm 0.33$ & $2.61 \pm 0.42$ & $0.266 \pm 0.044$ & & \\
\hline $33 \mathrm{~km}$ & & 10 & $8.52 \pm 0.32$ & $1.79 \pm 0.42$ & $0.210 \pm 0.050$ & & \\
\hline $52 \mathrm{~km}$ & & 10 & $8.18 \pm 0.18$ & $0.91 \pm 0.24$ & $0.110 \pm 0.029$ & & \\
\hline \multirow[t]{2}{*}{$\mathrm{D}$} & $42^{\circ} 44 \mathrm{~N}-8^{\circ} 31 \mathrm{E}$ & 30 & $9.70 \pm 0.47$ & $1.42 \pm 0.47$ & $0.146 \pm 0.052$ & 38.767 & 18.815 \\
\hline & & 1000 & $13.15 \pm 0.70$ & $\begin{array}{r}0.85 \pm 0.25 \\
\text { Medatlante I }\end{array}$ & $0.064 \pm 0.016$ & 39.179 & 12.851 \\
\hline \multirow[t]{2}{*}{$\mathrm{F}$} & $36^{\circ} 41 \mathrm{~N}-1^{\circ} 12 \mathrm{~W}$ & 10 & & & $0.174 \pm 0.009$ & 36.774 & 15.426 \\
\hline & & 1000 & $12.87 \pm 0.62$ & $0.49 \pm 0.04$ & $0.038 \pm 0.004$ & 38.429 & 12.798 \\
\hline I & $35^{\circ} 53 \mathrm{~N}-6^{\circ} 35 \mathrm{~W}$ & 450 & $8.42 \pm 0.30$ & $0.67 \pm 0.07$ & $0.079 \pm 0.009$ & 35.977 & 12.489 \\
\hline $\mathrm{J}$ & $35^{\circ} 52 \mathrm{~N}-7^{\circ} 06 \mathrm{~W}$ & 200 & $7.32 \pm 0.12$ & $0.76 \pm 0.05$ & $0.103 \pm 0.006$ & 35.777 & 13.466 \\
\hline \multirow[t]{6}{*}{ Nicole } & $36^{\circ} 27 \mathrm{~N}-10^{\circ} 35 \mathrm{~W}$ & 500 & $6.62 \pm 0.32$ & $0.50 \pm 0.07$ & $0.076 \pm 0.010$ & 35.578 & 11.000 \\
\hline & & 600 & $7.00 \pm 1.00$ & $0.45 \pm 0.08$ & $0.064 \pm 0.006$ & 35.876 & 11.613 \\
\hline & & 800 & $9.28 \pm 0.35$ & $0.56 \pm 0.09$ & $0.062 \pm 0.010$ & 36.082 & 11.344 \\
\hline & & 1000 & $9.50 \pm 0.50$ & $0.77 \pm 0.12$ & $0.081 \pm 0.004$ & 36.448 & 12.126 \\
\hline & & 1200 & $9.65 \pm 0.13$ & $0.90 \pm 0.09$ & $0.093 \pm 0.009$ & 36.457 & 11.771 \\
\hline & & 1700 & $9.49 \pm 2.60$ & $\begin{array}{c}0.19 \pm 0.17 \\
\text { Medatlante } 2\end{array}$ & $0.020 \pm 0.018$ & 35.678 & 7.249 \\
\hline \multirow[t]{2}{*}{ E } & $40^{\circ} 12 \mathrm{~N}-6^{\circ} 08 \mathrm{E}$ & 10 & $8.53 \pm 0.21$ & $1.79 \pm 0.19$ & $0.209 \pm 0.022$ & 37.331 & 25.064 \\
\hline & & 1000 & $13.13 \pm 0.11$ & $0.61 \pm 0.07$ & $0.046 \pm 0.005$ & 38.436 & 12.847 \\
\hline $\mathrm{G}$ & $36^{\circ} 44 \mathrm{~N}-1^{\circ} 10 \mathrm{~W}$ & 10 & $8.11 \pm 0.24$ & $1.55 \pm 0.24$ & $0.191 \pm 0.030$ & 36.555 & 21.459 \\
\hline $\mathrm{H}$ & $36^{\circ} 00 \mathrm{~N}-4^{\circ} 10 \mathrm{~W}$ & 10 & $8.16 \pm 0.24$ & $1.80 \pm 0.22$ & $0.221 \pm 0.027$ & 36.429 & 21.398 \\
\hline K & $36^{\circ} 00 \mathrm{~N}-12^{\circ} 00 \mathrm{~W}$ & 10 & $6.55 \pm 0.10$ & $1.24 \pm 0.12$ & $0.189 \pm 0.018$ & 36.440 & 23.238 \\
\hline L & $36^{\circ} 00 \mathrm{~N}-12^{\circ} 43 \mathrm{~W}$ & 10 & $6.97 \pm 0.23$ & $1.41 \pm 0.23$ & $0.202 \pm 0.034$ & 36.400 & 23.288 \\
\hline $\mathbf{M}$ & $36^{\circ} 01 \mathrm{~N}-14^{\circ} 12 \mathrm{~W}$ & 10 & $6.80 \pm 0.24$ & $1.05 \pm 0.27$ & $0.154 \pm 0.040$ & 36.431 & 23.116 \\
\hline W & $35^{\circ} 00 \mathrm{~N}-17^{\circ} 01 \mathrm{~W}$ & 10 & $5.84 \pm 0.13$ & $1.12 \pm 0.16$ & $0.192 \pm 0.027$ & 36.681 & 23209 \\
\hline $\mathbf{P}$ & $34^{\circ} 30 \mathrm{~N}-16^{\circ} 30 \mathrm{~W}$ & 10 & $6.22 \pm 0.11$ & $0.91 \pm 0.11$ & $0.146 \pm 0.018$ & 36.427 & 23.450 \\
\hline Q & $34^{\circ} 00 \mathrm{~N}-18^{\circ} 25 \mathrm{~W}$ & 10 & $6.38 \pm 0.44$ & $1.10 \pm 0.14$ & $0.172 \pm 0.025$ & 36.576 & 24.194 \\
\hline \multirow[t]{10}{*}{ Yseult } & $36^{\circ} 30 \mathrm{~N}-15^{\circ} 35 \mathrm{~W}$ & 10 & $5.91 \pm 0.13$ & $0.88 \pm 0.15$ & $0.149 \pm 0.028$ & 36.430 & 23.780 \\
\hline & & 100 & $7.02 \pm 0.14$ & $1.05 \pm 0.17$ & $0.150 \pm 0.026$ & 36.088 & 15.094 \\
\hline & & 450 & $9.26 \pm 0.15$ & $0.41 \pm 0.13$ & $0.044 \pm 0.014$ & 35.623 & 11.389 \\
\hline & & 850 & $9.21 \pm 0.19$ & $0.53 \pm 0.18$ & $0.058 \pm 0.019$ & 35.923 & 10.459 \\
\hline & & 1100 & $8.50 \pm 0.25$ & $0.70 \pm 0.10$ & $0.083 \pm 0.012$ & 36.122 & 10.416 \\
\hline & & 1400 & $9.52 \pm 0.30$ & $0.28 \pm 0.24$ & $0.029 \pm 0.025$ & 35.602 & 7.281 \\
\hline & & 1800 & $8.46 \pm 0.40$ & $0.25 \pm 0.29$ & $0.030 \pm 0.035$ & 35.198 & 4.740 \\
\hline & & 2600 & $12.23 \pm 0.30$ & $0.22 \pm 0.25$ & $0.018 \pm 0.020$ & & \\
\hline & & 2900 & $14.15 \pm 0.23$ & $0.33 \pm 0.19$ & $0.023 \pm 0.013$ & & \\
\hline & & 3100 & $15.04 \pm 0.20$ & $0.42 \pm 0.16$ & $0.280 \pm 0.010$ & & \\
\hline
\end{tabular}






Figure 1. Location of samples collected in the NW Mediterranean Sea and in the NE Atlantic Ocean. All sample locations and data are listed in Table 1. The open symbols show position of Meddies Nicole and Yseult sampled during Medatlante cruises. The hatched area is the deep water formation area. The arrows show the location of the Ligurian Current in the studied area.

major constituents of the MOW. This Deep Water is formed in the northern area of the western basin (Gulf of Lion, Ligurian Sea). Deep water renewal occurs each year during winter and early spring when the cooling of superficial waters increases their density and induces vertical convection [Jacques and Treguer, 1986]. Therefore at first we studied the Deep Water formation area (Figure 1).

Figure 2 shows salinity data (L. Prieur and J. Raunet, personal communication, 1989) and radium activities in surface waters along a transect between Villefranche and Calvi in the Ligurian Sea. As a comparison, we presented radium activities in Villefranche Bay: both radium isotopes are at higher levels due to the proximity of the shallow sediments $(<40 \mathrm{~m})$. Along the transect, surface ${ }^{226} \mathrm{Ra}$ activities are relatively constant, varying from ( 8 to 10$) \times 10^{-2} \mathrm{dpm} \mathrm{L}-1$. The half-life of $226 \mathrm{Ra}, 1600$ years, is too long to allow an observable decay over short timescales. On the other hand, ${ }^{228} \mathrm{Ra}$ activities decrease by a factor of 3 from the coast to the central site. The ${ }^{228} \mathrm{Ra}$ distribution reflects the presence of two distinct surficial water masses, separated by a frontal area, as highlighted by salinity curve. The Ligurian Current, which flows between the coast and a distance of approximately $30 \mathrm{~km}$ offshore [Béthoux et al., 1988], is enriched in $\mathrm{Ra}$ by input from interstitial waters of coastal sediment. This input sustains ligh activities around $2.5 \times 10^{-2} \mathrm{dpm} \mathrm{L}^{-1}$ into the current body. More than $30 \mathrm{~km}$ offshore, the central water mass contains ${ }^{228} \mathrm{Ra}$ activities typical of open ocean waters. At the central site of the transect, surface water is unaffected by input due to

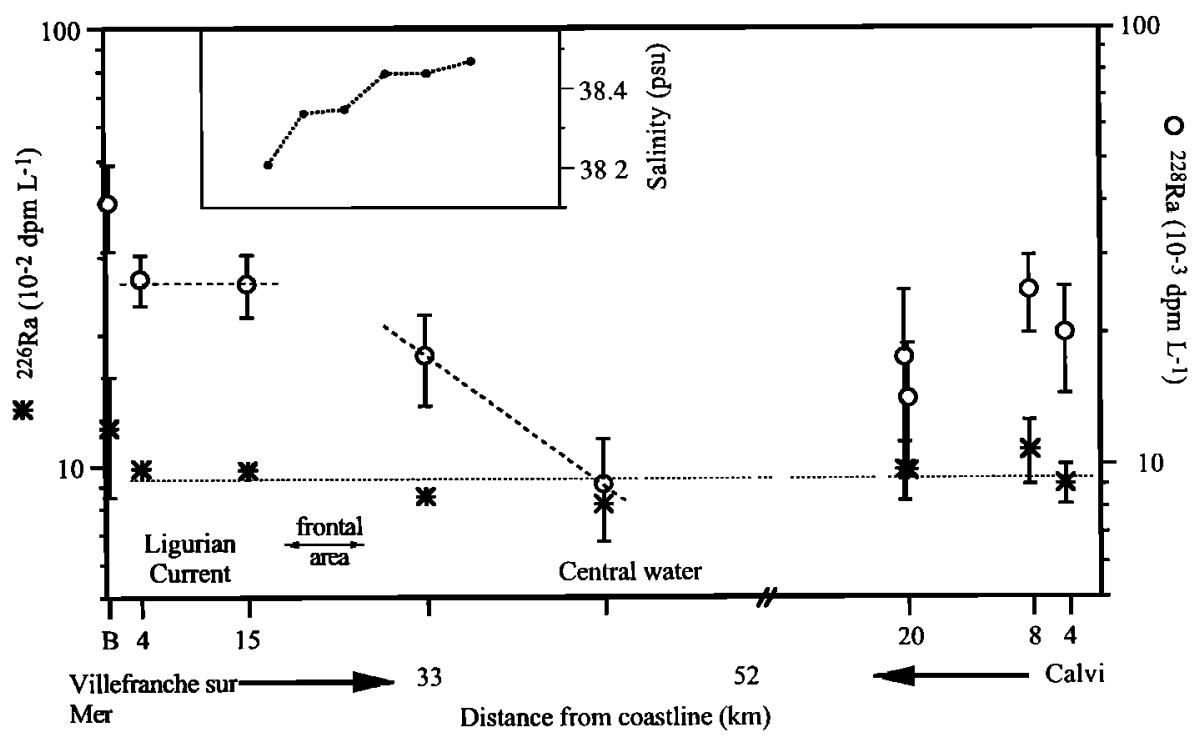

Figure 2. Ra versus distance from coastline relationshıp for surface samples of Villefranche-Calvi transect in the Ligurian Sea. The salinity is expressed in psu. 
the distance from sediments, either coastal or deep, the water column depth being around $2500 \mathrm{~m}$.

Seawater ${ }^{228} \mathrm{Ra}$ data may be used to calculate apparent horizontal eddy diffusion coefficients [Kaufman et al., 1973]. The observed gradient in ${ }^{228} \mathbf{R a}$ concentrations in surface water between coastline and central sites probably reflects eddy diffusion of ${ }^{228} \mathrm{Ra}$ perpendicular to the mean advective flow of the Ligurian Current. In the simplest case, the ${ }^{228} \mathrm{Ra}$ distribution can be treated as a balance between eddy diffusion and radioactive decay of ${ }^{228} \mathrm{Ra}$. At steady state

$$
K_{\mathrm{y}} \frac{\mathrm{d}^{2} \mathrm{c}}{\mathrm{dz}^{2}}-\lambda \mathrm{c}=0
$$

With boundary conditions $\mathrm{c}=\mathrm{c}_{0}$ at $\mathrm{z}=0$ and $\mathrm{c}=0$ at $\mathrm{z}=\infty$, the solution of (1) is [Knauss et al., 1978]

$$
\begin{gathered}
\mathrm{c}=\mathrm{c}_{0} \mathrm{e}^{\left(-\mathrm{y} / \mathrm{y}^{*}\right)} \quad \mathrm{y}^{*}=\sqrt{\frac{\mathrm{K}_{\mathrm{y}}}{\lambda}} \\
K_{\mathrm{y}}=\left[\frac{\mathrm{y}}{\operatorname{Ln}\left(\mathrm{c}_{0} / \mathrm{c}\right)}\right]^{2} \times \lambda
\end{gathered}
$$

$\lambda$ the decay constant of ${ }^{228} \mathrm{Ra}$, $\mathrm{y}$ the distance between the two points, $y^{*}$ the scale length and $K_{y}$ the coefficient of horizontal eddy diffusion.

We calculate $K_{\mathrm{y}}$, the apparent horizontal eddy diffusion coefficient, between 4 and $15 \mathrm{~km}$ offshore which may represent the diffusion of ${ }^{228} \mathrm{Ra}$ into the Ligurian Current water body. Even though the extent of the Ligurian Current varies seasonally, with a maximum extension of about $20-25 \mathrm{~km}$ offshore, these two points are always in the central current body [Béthoux et al., 1988]. Into the current body, ${ }^{228} \mathrm{Ra}$ activities give a $K_{y}$ of around $7 \times 10^{6} \mathrm{~cm}^{2} \mathrm{~s}^{-1}$, with a characteristic scale length of about $420 \mathrm{~km}$ (Figure 2). As the central water could be affected by deep water renewal during winter, such calculation is not realistic for the data obtained at 33 and $52 \mathrm{~km}$ offshore. Nevertheless, the decrease of ${ }^{228} \mathrm{Ra}$ between the current body and the central water contents, beyond the influence of the Ligurian Current, indicates that Ligurian Current acts as a barrier against the propagation toward the central water of species diffusing from coastal shelf.

In the same Deep Water formation area, at $1000 \mathrm{~m}$ depth, ${ }^{228} \mathrm{Ra}$ activity is relatively high with levels of $0.85 \times 10^{-2} \mathrm{dpm}$ $\mathrm{L}^{-1}$, may be in relation with the winter vertical convection (the superficial seawater which flows down during these events supplies ${ }^{228} \mathrm{Ra}$ ). By comparison, Atlantic or Pacific ${ }^{228} \mathrm{Ra}$ concentrations at the same depth are usually much lower, less than $0.5 \times 10^{-2} \mathrm{dpm} \mathrm{L^{-1 }}$ [Moore et al., 1985].

Western Deep Water circulation in the Western Mediterranean basin. The western Deep Water (DW), which is formed by deep convection in the north area of the Western Mediterranean basin, flows toward the Straits of Gibraltar, below $600 \mathrm{~m}$ depth with nearly constant hydrological characteristics: $\mathrm{T}=12.74^{\circ} \mathrm{C}$ and $\mathrm{S}=38.44$ psu [Gascard and Richez, 1985]. The western DW was studied from its formation area up to its outflow through the Gibraltar Straits. This water mass, identified by its temperature and salinity signature, was sampled at $1000 \mathrm{~m}$ (Figure 1) : (1) south of the formation area (E), and (2) at the east side of the Alboran Sea (F). Radium-226 activities are relatively constant with values of about $13 \times 10^{-2}$ $\mathrm{dpm} \mathrm{L}^{-1}$, which is not surprising, taking into account the short residence time of water in this basin [Andrié and Merlivat, 1988].

For ${ }^{228} \mathrm{Ra}$, on the other hand, we observe a continuous decrease in activity outside the formation area as Deep Water propagates to the west side of the basin. These variations reflect the aging of the Deep Water during its motion from the NW basin to the Alboran Sea. More particularly, the comparison between sites $\mathrm{E}$ and $\mathrm{F}$ indicates a significant decrease of ${ }^{228} \mathrm{Ra}$ from (0.61 to 0.49$) \times 10^{-2} \mathrm{dpm} \mathrm{L}^{-1}$ at $1000 \mathrm{~m}$ As the western Deep Water propagates westward without significant dilution, the decrease in ${ }^{228} \mathrm{Ra}$ activity can be ascribed to the decay of the isotope and can be used to calculate a transit time of the water mass between the two sites. The hypothesis is that deep advection is horizontal and without mixing. Moreover the depth of $1000 \mathrm{~m}$ in a $2500-\mathrm{m}$ column allows us to neglect diffusive input of $\mathrm{Ra}$ from sediment. The equation is derived from the decay law

$$
t=\lambda-1 \operatorname{Ln} \frac{A_{0}}{A}
$$

$A_{0}$ and $A$ the activities of $R a$ at both sites, $t$ the time elapsed which corresponds to the observed decay of ${ }^{228} \mathrm{Ra}$, and $\lambda$ the decay constant of ${ }^{228} \mathrm{Ra}$.

With the values $A_{0}=(0.61 \pm 0.07) \times 10^{-2} \mathrm{dpm} \mathrm{L} \mathrm{L}^{-1}, \mathrm{~A}=$ $(0.49 \pm 0.04) \times 10^{-2} \mathrm{dpm} \mathrm{L-1}, \lambda\left[{ }^{228} \mathrm{Ra}\right]=0.1205 \mathrm{y}^{-1}$, we obtained a mean transit time of the Western Deep Water from the Southern Lion Gulf (E) to the Alboran Sea (F) of 1.8 years, with range from 0.6 to 2.9 years. Taking into account the shortest distance between the two sites, considered as a direct transect, it is then possible to calculate a mean translation velocity of the deep water mass of about $1.5 \mathrm{~cm} \mathrm{~s}^{-1}(0.9-4.5)$. Andrié and Merlivat [1988] established the residence time of the water in the Western Mediterranean basin with transient tracers. These authors calculate a transit time of the deep water, with the same hypothesis (deep horizontal advection, no exchange), of 6.5 years between the Sardaigne Straits and Alboran Sea: such time implies a translation velocity of 0.5 $\mathrm{cms}^{-1}$. Despite the fact that these two studies concern two distinct transects and are based on different tracers $\left({ }^{228} \mathrm{Ra}\right.$, 5.75 years; ${ }^{3} \mathrm{He}, 12.4$ years), the estimated transit times are not drastically different. Both are in agreement with the assumption of a rapid turnover of the Mediterranean water mass already inferred from the mean of salt and heat budgets.

\section{Northeastern Atlantic Ocean}

Surface activity. Off the Gibraltar Straits, Atlantic surface water contains relatively constant values of Ra. Ratios of ${ }^{228} \mathrm{Ra} /{ }^{226} \mathrm{Ra}$ previously determined in the same area show a discrimination between coastal and open ocean water masses [Van Geen et al., 1991]. Surface Atlantic ${ }^{228} \mathrm{Ra} / 226 \mathrm{Ra}$ activities obtained during Medatlante cruises are plotted versus salinity on Figure 3. The range of activity ratios is comparable with that measured in earlier work in the Gulf of Cadiz [Van Geen et al., 1991]. These authors have defined three zones: (1) Spanish shelf water with activity ratios up to 0.57 , (2) more saline Moroccan shelf water with ratios not exceeding 0.26 , and (3) surface Atlantic water within the Strait with ratios less than 0.2 . Our surface ratio values are in good agreement with the third group even for distant points.

Excess of ${ }^{228} \mathrm{Ra}$ in Meddies. After investigation of the Mediterranean Deep Water, we have focused on two Meddies surveyed during Medatlante cruises. The first was localized at $36^{\circ} 27^{\prime} \mathrm{N}, 10^{\circ} 35^{\prime} \mathrm{W}$, characterized by a warm, salt, surface mixed layer (Figure 4). Below $100 \mathrm{~m}$ depth, temperature and salinity decrease rapidly to reach minimum values $\left(\mathrm{T}=11^{\circ} \mathrm{C}\right.$, $\mathrm{S}=35.578 \mathrm{psu}$ ) at a depth of $500 \mathrm{~m}$ Below $500 \mathrm{~m}$, salinity increases to a maximum at $1200 \mathrm{~m}(36.457 \mathrm{psu})$ and indicates that a Meddy called Nicole lies between 700 and $1500 \mathrm{~m}$ 




Figure 3. Ratio of ${ }^{228} \mathrm{Ra} / 226 \mathrm{Ra}$ versus salinity relationship for surface samples. Open circles indicate values published by Van Geen et al. [1991].

depth. Nicole appears to be a large lens about $100 \mathrm{~km}$ in diameter. At its base, $\mathrm{T}$ and $\mathrm{S}$ values are characteristic of North Atlantic Deep Water. This hydrologic structure is reflected in the distribution of ${ }^{228} \mathrm{Ra}$ between 500 and $1700 \mathrm{~m}$ depth. Because of its supply by diffusion from sediments, ${ }^{228} \mathrm{Ra}$ activities usually display strong vertical gradients [Moore, 1969]. Moreover, ${ }^{228} \mathrm{Ra}$ activities are often lower than $5 \times 10^{-3}$ dpın $\mathrm{L}^{-1}$ in deep and intermediate waters [Moore et al., 1985; Trier et al., 1972]. Indeed, under the thermocline, ${ }^{228} \mathrm{Ra}$ decreases rapidly to reach activities less than $5 \times 10^{-3} \mathrm{dpm} \mathrm{L-1}$ at 500 and $600 \mathrm{~m}$. At greater depths, ${ }^{228} \mathrm{Ra}$ increases up to $9.0 \times 10^{-3} \mathrm{dpm} \mathrm{L}^{-1}$ at $1200 \mathrm{~m}$ (Figure 4). These high concentrations of ${ }^{228} \mathrm{Ra}$ measured in Meddy water are in contrast to the low levels in the surrounding Atlantic water.
Such high levels indicate the presence of a water mass which has been recently in contact with sediments.

Meddies mostly constitute MOW which flows out into the Atlantic. At the Gibraltar Straits, MOW flows out of the Mediterranean basin at depth because of its greater density in comparison with Atlantic inflow. Around $150 \mathrm{~m}$ depth, the shear between the two layers flowing in opposite directions leads to eddy mixing. The effect is to reduce the salinity of the MOW [Minas et al., 1991]. This dilution would also influence the $\mathrm{Ra}$ concentration. Sediment-water exchange is another process than could affect the Ra concentration of the MOW. During the crossing of the Straits, MOW is in contact with the sediments which presumably releases $\mathrm{Ra}$ and causes the Ra content of MOW to rise. Evaluating $\mathrm{Ra}$ input to the



Figure 4. Vertical profiles of salinity (psu), ${ }^{228} \mathrm{Ra}$ and ${ }^{228} \mathrm{Ra}\left(10^{-3}\right.$ and $\left.10^{-2} \mathrm{dpm} \mathrm{L}^{-1}\right)$ at the site Nicole $\left(36^{\circ} 30^{\prime} \mathrm{N}-15^{\circ} 35 \mathrm{~W}\right.$, open circles, water column depth $\left.4750 \mathrm{~m}\right)$ and $Y$ seult $\left(36^{\circ} 27^{\prime} \mathrm{N}-10^{\circ} 35^{\prime} \mathrm{W}\right.$, crosses, water column depth $3170 \mathrm{~m}$ ). 
MOW in the vicinity of the Straits is complicated, because the exchange of water itself through the Straits of Gibraltar is a complex process which involves mixing of various water masses (Surface Atlantic water, Levantine Intermediate water and western Deep Water [Gascard and Richez, 1985]). The comparison of $\mathrm{Ra}$ data $\left(36^{\circ} 41^{\prime} \mathrm{N}-1^{\circ} 12^{\prime} \mathrm{W}\right.$ (F) and $35^{\circ} 53^{\prime} \mathrm{N}$ $6^{\circ} 35^{\prime} \mathrm{N}$ (I) stations) on the Mediterranean and Atlantic sides of the Straits clearly indicates an increase in activities of both $\mathrm{Ra}$ isotopes. If we correct the Atlantic water contribution for Nicole, the excess ${ }^{228} \mathrm{Ra}$ activity at $1200 \mathrm{~m}$ is $35 \pm 5 \%$ in comparison to Mediterranean deep water. There is therefore strong evidence that input of Ra occurs when MOW is in contact with the sediment during the crossing of the Straits and continues as long as this water stays in contact with shallow sediment of the Spanish continental shelves.

The second Meddy was sampled at $36^{\circ} 30^{\prime} \mathrm{N}, 15^{\circ} 35^{\prime} \mathrm{W}$ in summer 1989. In the upper layer, this site is similar to the Nicole site and exhibits a surface mixed layer of high temperature and salinity (Figure 4). Below the mixed layer, temperature and salinity decrease rapidly. Down to $500 \mathrm{~m}$ depth, they both increase to reach maximum values at $1100 \mathrm{~m}$ which corresponds to the center of the lens. This Meddy, called Yseult, is about half the size and is characterized by weaker salinity and temperature maxima than Nicole. Below $1500 \mathrm{~m}, \mathrm{~T}$ and $\mathrm{S}$ are typical of the deep Atlantic. As for Nicole, the ${ }^{228} \mathrm{Ra}$ concentration maximum is at the surface. Radium228 diminishes below the thermocline, reaches high levels, $(0.7 \pm 0.1) \times 10^{-2} \mathrm{dpm} \mathrm{L}^{-1}$ at $1100 \mathrm{~m}$, at the Yseult immersion. As for the $T$ and $S$ signature, the maximum ${ }^{228} \mathrm{Ra}$ activity is lower than at Nicole. Two processes could explain this reduction. One is dilution by surrounding Atlantic waters. According to Armi et al. [1989], dilution limits the mean life to 2 or 3 years. In fact, as previously mentioned, surrounding Atlantic water at such depths contains lower levels of ${ }^{228} \mathrm{Ra}$ than the MOW, as a result of the absence of recent input. The second explanation is a longer advection time from the shelf source and therefore a decay of $228 \mathrm{Ra}$. Below $2500 \mathrm{~m}$, the gradual increase of ${ }^{228} \mathrm{Ra}$ could be ascribed to diffusion from sediment which lies at $3170 \mathrm{~m}$.

Unlike ${ }^{228} \mathrm{Ra}$, the two profiles activities of ${ }^{226} \mathrm{Ra}$, with its long half-life, are only slightly affected by the presence of Mediterranean water. The supply by diffusion from the sediments is negligible in comparison to ambient ${ }^{226} \mathrm{Ra}$ levels. Surface activities of ${ }^{226} \mathrm{Ra}$ off Gibraltar are in the range of (5.9 to 7.0$) \times 10^{-2} \mathrm{dpm} \mathrm{L}^{-1}$, slightly lower than those reported for West Atlantic upper waters [Moore, 1987]. This may reflect lower input from coastal shelf and reduced area of continental shelves on the eastern compared with the western side of the Atlantic.

Translation velocity of Meddy Yseult. The decrease of ${ }^{228} \mathrm{Ra}$ can be used to calculate the advection velocity of the MOW as was done for western Mediterranean Deep Water. The hypothesis is that we can use Nicole as a reference. Nicole has been localized in the vicinity of the Meddies formation area, and we can assume that $\mathrm{Ra}$ activities are relatively constant in the MOW. The calculation takes into account the two factors which explain the decrease of 228 $\mathrm{Ra}$ between Meddies Nicole and Yseult: the decay of ${ }^{228} \mathrm{Ra}$ and the dilution of MOW by Atlantic water. The effect of Atlantic water on ${ }^{228} \mathrm{Ra}$ activity can be corrected by calculating the dilution using temperature and salinity data. The calculated dilution of the Mediterranean water at $1100 \mathrm{~m}$ depth in comparison with the surrounding Atlantic water is $38 \%$.
When this dilution factor is applied to the ${ }^{226} \mathrm{Ra}$ activity, the calculated ${ }^{226} \mathrm{Ra}$ is $(8.50 \pm 0.15) \times 10^{-2} \mathrm{dpm} \mathrm{L}^{-1}$ : this value is in agreement with the measured value of $(8.20 \pm 0.20) \times 10^{-2} \mathrm{dpm}$ $\mathrm{L}^{-1}$ (Table 1). For ${ }^{228} \mathrm{Ra}$, the value calculated in the same manner is $(0.75 \pm 0.07) \times 10^{-2} \mathrm{dpm} \mathrm{L}^{-1}$ which can be compared to the measured activity of $(0.70 \pm 0.10) \times 10^{-2} \mathrm{dpm} \mathrm{L}^{-1}$. Due to the large errors on these values, the potential decay of ${ }^{228} \mathrm{Ra}$ does not clearly appear. However, it indicates that Yseult is probably young, less than 1.9 years. With additional sampling, age calculation could be better constrained.

The studied area includes many submarine obstacles such as Ormond, Gettysburg, and Josephine seamounts and the Madeira archipelago. The possible Meddy pathways around these seamounts covers a minimum distance of 350 miles between the two sites studied. Assuming a mean translation velocity of $3 \mathrm{~cm} \mathrm{~s}^{-1}$ for Meddies [Armi et al., 1989], we can calculate a minimum transit time of 8.2 months. These two estimates seem to indicate that the transit time is probably less than 1 year, in agreement with the estimation based on biological tracers [Savenkoff et al., 1993].

\section{Conclusions}

This study demonstrates the usefulness of $\mathrm{Ra}$ isotopes as internal tracers for following the MOW from the Mediterranean deep water formation area to the NE Atlantic Ocean. In the Western Mediterranean Sea, the observed gradient in ${ }^{228} \mathrm{Ra}$ activities in Ligurian Sea surface seawater may be attributed to the transport of ${ }^{228} \mathrm{Ra}$ away from the coast by eddy diffusion perpendicular to the Ligurian Current. Simpler one-dimensional, steady state models do not produce realistic estimates of horizontal mixing. More extensive sampling programs are needed to realize the full potential of this tracer for oceanic mixing rates. In its formation area, the ${ }^{228} \mathrm{Ra}$ activity of the Deep Mediterranean Water is as high as open ocean surface waters values. This may be explained by the annual renewal of ${ }^{228} \mathrm{Ra}$ during winter convection. As the Deep Water flows westward, the observed decay of ${ }^{228} \mathrm{Ra}$ with distance from the source allows us to calculate a mean translation velocity of the deep water mass of the order of 1.5 $\mathrm{cm} \mathrm{s}^{-1}$ which is consistent with a rapid renewal time of the western Mediterranean basin.

In the Atlantic Ocean, the presence of Meddies Nicole and Yseult is strikingly reflected by ${ }^{228} \mathrm{Ra}$ profiles in the water column. Indeed, the Meddies contain activities of ${ }^{228} \mathrm{Ra}$ which are significantly different from surrounding waters. This feature reflects the presence of the MOW which has recently been in contact with sediment in the vicinity of the Gibraltar Straits. After correction of the dilution of Yseult water by the surrounding Atlantic water using salinity and 226Ra data, it is possible to calculate a lower limit of the velocity of Yseult of around $1 \mathrm{~cm} \mathrm{~s}^{-1}$. This result, along with its biological signature [Savenkoff et al., 1993] seems to indicate that Yseult has an age of less than 1 year. With additional sampling, better constrained ages could be obtained. The use of such internal tracers is perhaps the only way to constrain the age of these features without following them for several years. This work has been possible with the improvement of a lowbackground, high-efficiency detector which has been placed in the LSM and allows us to measure ${ }^{228} \mathrm{Ra}$ on small volume samples with reduced errors and laboratory work. 
Acknowledgements. This is a contribution to the France-JGOFS program financed by the CNRS (Dyfamed, Medatlante). During the Medatlante cruises, vertical conductivity-temperature-depth profiles were established by C. Bournot, J. Raunet, and D. Taillez. We thank the logistic staff of the LSM for its help in working up the counting installation. The help of G. Copin-Montégut was useful for retrieving salinity data of the Ligurian surface water. We also thank $M$. Bender and P. Newton for useful comments. This is CFR contribution 1684.

\section{References}

Andrić, C., and L. Merlivat, Tritium in western Mediterranean Sca during 1981 Phycemed cruise, Deep Sea Res., 65, 547-567, 1988.

Armi, L., D. Hcbert, N. Oakey, P.L. Richardson, H.T. Rossby, and B. Ruddick, The history and decay of the Mediterranean salt Icns, Nature, 333, 649-651, 1988.

Armi, L., D. Hebert, N. Oakey, J.F. Price, P.L. Richardson, H.T. Rossby, and $B$. Ruddick, Two years in the life of a mediterranean salt lens, $J$. Phys. Oceanogr., 19, 354-370, 1989.

Béthoux, J.P., L. Prieur, and J.-H. Bong, The Ligurian current off the French Rivicra, Oceanol. Acta, SP, 59-67, 1988.

Gascard, J.C., and C. Richez, Water masses and circulation in the western Alboran Sea and in the Straits of Gibraltar, Prog. Oceanogr., 15, 157-216, 1985.

Jacques, G., and P. Treguer, Ecosystèmes Pélagiques Marins, 243 pp., Masson, Paris, 1986.

Kaufinan, A., R.M. Trier, W.S. Broecker, and H.W. Feely, Distribution of $228 \mathrm{Ra}$ in the world ocean, J. Geophys. Res., 78, 8827-8848, 1973.

Knauss, K.G., T.-L. Ku, and W.S. Moore, Radium and thorium isotopes in the surface waters of the cast Pacific and coastal southern California, Earth Planet. Sci. Lett., 39, 235-249, 1978.

Marshall, J., Submarine salt lenses, Nature, 333, 594-595, 1988.

Minas, H.J., B. Coste, P. Le Corre, M. Minas, and P. Raimbault, Biological and geochemical signatures associated with the water circulation through the Strait of Gibraltar and in the Western Alboran Sca, J. Geophys. Res., 96, 8755-8771, 1991.

Moore, W.S., The measurement of ${ }^{228} \mathrm{Ra}$ and ${ }^{228} \mathrm{Th}$ in scawater, $J$. Geophys. Res., 74, 694-704, 1969.

Moore, W.S., ${ }^{22 R} \mathrm{Ra}$ in the south Atlantic Bight, J. Geophys. Res., 92, $5177-5190,1987$.
Moorc, W.S., and P.H Santschi, Ra-228 in the deep Indian Ocean, Deep Sea Res., 33, 107-120, 1986.

Moore, W.S., and J.F. Todd, Radium isotopes in the Orinoco Estuary and Eastcrn Caribbean Sca, J. Geophys. Res., 98, 2233-2244, 1993.

Moore, W.S., R.M. Kcy, and J.L. Sarmiento, Techniques for precisc Inapping of ${ }^{226} \mathrm{Ra}$ and ${ }^{228} \mathrm{Ra}$ in the ocean, J. Geophys. Res., 90 , 6983-6994, 1985.

Orr, J.C., Evaluation of counting methods for oceanic ${ }^{228} \mathrm{Ra}, J$. Geophys. Res., 93, 8265-8278, 1988.

Reid, D.F., W.S. Moore, and W.S. Sackett, Temporal variation of ${ }^{228} \mathrm{Ra}$ in the near-surface gulf of Mexico, Earth Planet. Sci. Lett., 43, 227236, 1979.

Reyss, J.-L., S. Schınidt, F. Legeleux, and P. Bonté, Large, low background well-type detectors for measurements of environmental radioactivity, Nucl. Instrum. Methods. Phys. Res., Sect.A, 357, 391$397,1995$.

Rossby, T., Five drifters in a Mediterranean salt lens, Deep Sea Res., 35 , 1653-1663, 1988.

Sarmicnto, J.L., C.G.H. Rooth, and W.S. Broccker, Radium 228 as a tracer of basin wide processes in the Abyssal ocean, J. Geophys. Res., 87, 9694-9698, 1982.

Savenkoff, C., D. Lefevre, M. Denis, and C.E. Lambert, How do microbial communities keep living in the Mediterranean Outflow within N.E. Atlantic intermediate waters?, Deep Sea Res., 40, 627641,1993

Trier, R.M., W.S. Broecker, and H.W. Feely, ${ }^{228}$ Ra profile at the second GEOSECS intercalibration station, 1970, in the North Atlantic, Earth Planet. Sci. Lett., I6, 141-145, 1972.

Van Geen, A., E.A. Boyle, and W.S. Moore, Trace metal enrichments in waters of the Gulf of Cadiz, Spain, Geochim. Cosmochim. Acta, 55. 2173-2191, 1991.

Yamada, M., and Y. Nozaki, Radium isotopes in coastal and open ocean surface waters of the Western North Pacific, Mar. Chem., 19, 379389,1986

J-L. Rcyss and S. Schmidt, Centre des Faibles Radioactivités, Laboratoirc Mixte CNRS-CEA, Gif sur Yvette Cedex, F-91198 France. (c-mail: schmidt@cfr.cnrs-gif.fr)

(Received April 1, 1993; revised August 15, 1994; accepted February 13, 1995.) 
